Article

\title{
Runoff and Solute Outputs under Different Land Uses: Long-Term Results from a Mediterranean Mountain Experimental Station
}

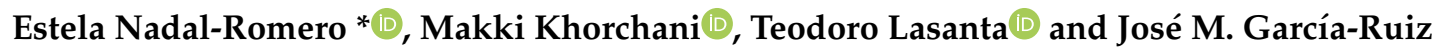 \\ Instituto Pirenaico de Ecología, Procesos Geoambientales y Cambio Global, IPE-CSIC, 50059 Zaragoza, Spain; \\ makki.khorchani@ipe.csic.es (M.K.); fm@ipe.csic.es (T.L.); humberto@ipe.csic.es (J.M.G.-R.) \\ * Correspondence: estelanr@ipe.csic.es; Tel.: +34-976-369-393
}

Received: 1 April 2019; Accepted: 5 May 2019; Published: 9 May 2019

check for updates

\begin{abstract}
Water availability and quality in Mediterranean environments are largely related to the spatial organisation of land uses in mountain areas, where most water resources are generated. However, there is scant data available on the potential effects of land use changes on surface water chemistry in the Mediterranean mountain region. In order to address this gap in the research, this study investigates the effects of various mountain Mediterranean land covers/land uses on runoff water yielded and water chemistry (solute concentrations and loads) using data from the Aísa Valley Experimental Station (Central Pyrenees) for a long-term period (1991-2011). Nine land covers have been reproduced in closed plots, including dense shrub cover, grazing meadows, cereal, fallow land, abandoned field, shifting agriculture (active and abandoned) and 2 burned plots (one burned in 1991 and the second one burned twice in 1993 and 2001). Results show that all solute concentrations differed among land uses, with agricultural activity producing significantly higher solute loads and concentrations than the other types. Two groups have been identified: (i) the lowest solute concentrations and the smallest quantities of solute loads are recorded in the dense shrub cover, the plot burned once (at present well colonized with shrubs), meadows and abandoned field plots; (ii) the plot burned twice registered moderate values and the highest solute concentrations and loads are found in cereal, fallow land and shifting agriculture plots. Water chemistry is clearly dominated by $\mathrm{Ca}^{2+}$ and $\mathrm{HCO}_{3}{ }^{-}$concentrations, whereas other solutes are exported in very low quantities due to the poor nutrient content of the soil. These results complete the information published previously on soil erosion under different land uses in this experimental station and help to explain the evolution of land cover as a consequence of shifting agriculture, cereal farming on steep slopes and the use of recurrent fires to favour seasonal grazing. They also suggest that promoting the development of grazing and cutting meadows is a good strategy to reduce not only soil erosion but also the loss of nutrients.
\end{abstract}

Keywords: solutes; land uses; soil erosion; water quality; Central Pyrenees

\section{Introduction}

The quality and availability of water resources constitute one the most important environmental problems in many countries of the world (i.e., [1]). In the Mediterranean basin, water availability is scarce, with strong seasonal contrasts and most of the flows are produced in mountain rivers [2,3], while water demand is constantly increasing, especially in the lowlands, due to the growth in population and urbanization, the expansion of irrigated areas and greater water consumption of the industrial and tourism sectors [4-6]. García-Ruiz et al. [7] indicated that Mediterranean countries are among the most under threat worldwide for water stress, due to high inter-annual and seasonal rainfall variability, revegetation processes and a predicted decrease in river flows in the coming decades. 
Giorgi [8] considered, on a global scale, the Mediterranean basin as a "hot spot" due to the limitation of water resources.

Furthermore, it is well known, that the evolution of surface water resources is controlled by two groups of environmental factors that are variable on a temporal scale: climate and land uses and land covers (hereafter, LULC). In the Mediterranean basin, future scenarios suggest that water resources will decrease as temperatures and evapotranspiration increase, while snow cover decreases $[7,9,10]$. On the other hand, LULC show an increase in vegetation cover due to the advance of shrubs and forests in abandoned lands $[11,12]$. The increase in vegetation cover implies a greater evapotranspiration and interception $[13,14]$ and higher water consumption by vegetation [15], thus reducing the surface flows of Mediterranean rivers and the water for filling reservoirs [16].

Revegetation processes in European Mediterranean mountain areas constitute an important problem for land managers, not only for their implications in the decrease of water resources [15-17] but also for the increase in fires [18], landscape homogenization, with less biodiversity and aesthetic quality $[19,20]$, degradation and loss of grazing resources [21,22] and ecosystem services [23,24]. To reduce the negative effects of revegetation processes, land managers have implemented public policies that try to control the revegetation process: prescribed fires [22,25] and shrub clearings [26-28].

On the other hand, in Southern and Eastern Mediterranean countries, agriculture is still practiced in many mountain areas to supply local population or for export, cultivating marginal areas (with low soil fertility and steep slopes) and in extreme cases, even using shifting agriculture systems. However, in other mountains, a process of land abandonment has started and is expected to intensify in the coming decades $[29,30]$. Most of the research related to land abandonment and revegetation processes in Mediterranean areas has focused on changes in the soil properties [31,32] and biodiversity and vegetation cover [33] and much less work has been done on soil erosion over the long-term [17,34]. Despite being generally accepted that solute outputs can be as important as other forms of surface erosion [35], studies that address the potential effects of land use changes on surface water chemistry and quality have been carried out to a lesser extent in the Mediterranean mountain region.

The loss of nutrients from different land uses (cultivated or uncultivated soils) contributes to a decrease in soil productivity and encourages soil erosion processes and other signs of ecosystem deterioration [36]. Many authors confirmed the extreme importance of LULC management in explaining the loss of nutrients and water quality (i.e., [37]) and changes in water chemistry associated with land use conversion have been demonstrated worldwide [38-40]. Most of these studies were carried out at catchment scale [41-43] and very little data are available at plot scale (which provides better knowledge on the effects from different land uses and a comparison with the same environmental conditions). For example, Oliveira et al. [44] and Ferreira et al. [45] observed an increase in solute loads due to anthropogenic-related land covers (agricultural and urban land). Likewise, Merchán et al. [46] showed that agricultural land use tends to increase the concentration of both solutes and suspended sediment. Nevertheless, the study of solute sources encounters many difficulties in anthropogenically-disturbed areas, in great part due to the wide range of LULC at catchment scale and the difficulty of directly observing the origin and pathways of solutes. One possible strategy is to reproduce different land uses in experimental plots and to measure runoff and sediment outputs during each storm event, while soil and gradient remains fixed. We are aware that the use of plots poses significant methodological problems and that an upscaling approach would be needed to interpret solute and suspended sediment values and sources at a catchment scale.

One of the great challenges for the future is to ensure sufficient water resources (quantity and quality), through the sustainable management of mountain areas [47]. To address this research gap, the present study aimed at providing further insights into solute concentration and total solute loads in nine different land uses and land covers (representing traditional and present LULC) in a Mediterranean mountain area (dense shrub cover, grazing meadows, cereal, fallow land, abandoned field, shifting agriculture (active and abandoned) and two burned plots). We hypothesized that different land uses conditioned water chemistry, solute concentration and export rates, with traditional agricultural uses 
recording the highest solute concentrations and loads. To improve our knowledge of the influence of land uses and land management on water chemistry, we analysed the information obtained from overland flow (surface runoff) in the Aísa Valley Experimental Station for 20 years (1991-2011), allowing us to define the solute patterns in both the traditional and present management systems.

\section{Materials and Methods}

\subsection{The Aisa Valley Experimental Station (1991-2011)}

The Aísa Valley Experimental Station (hereafter AVES) was installed in a representative slope located on a field abandoned 30 years ago. It is located at $1149 \mathrm{~m}$ a.s.l. on a south-facing slope completely covered by a dense shrubland of Genista scorpius L. and Rosa gr. canina L. The parent material is Eocene Flysch (alternate thin layers of sandstones and marls), at a 30\% slope gradient. The climate is sub-Mediterranean with mountain characteristics. The average annual precipitation is $1100 \mathrm{~mm}$ and the average annual temperature is $10^{\circ} \mathrm{C}$ (for more details see [17]).

Nine closed plots $(3 \mathrm{~m}$ width $\times 10 \mathrm{~m}$ length, with the same slope morphology, soil type and topographic conditions) were installed, including at the lower end a Gerlach trap and a system of tipping buckets connected to data loggers in order to record the runoff of each plot continuously. A pluviometer was also connected to a data logger. In the lowest part, a plastic collector to store runoff and sediment during rainfall events was installed in each plot. After each rainfall, a representative sample (about $2 \mathrm{~L}$ ) was collected and analysed in the laboratory for suspended sediment concentration, total solute concentration and solute composition (mean number of runoff events in the study period equals to 354 (per plot) and mean number of runoff events per year and plot equals to $18 \pm 8$ ). Chemical water analysis for a set of relevant elements was carried out $\left(\mathrm{Na}^{+}, \mathrm{K}^{+}, \mathrm{Ca}^{2+}, \mathrm{Mg}^{2+}, \mathrm{HCO}_{3}{ }^{-}\right.$, $\mathrm{Cl}, \mathrm{SO}_{4}{ }^{2-}, \mathrm{NO}_{3}{ }^{-}, \mathrm{SiO}_{2}, \mathrm{~N}-\mathrm{NO}_{3}{ }^{-}, \mathrm{N}_{-} \mathrm{NO}_{2}{ }^{-}, \mathrm{N}-\mathrm{NH}_{4}{ }^{-}$and $\mathrm{PO}_{4}{ }^{3-}$ ) over twenty years by means of ion chromatography (Metrohm 861 Advanced Compact IC) at the Laboratory of the Instituto Pirenaico de Ecología (IPE-CSIC).

Plots reproduced nine LULC (Figure 1) from traditional and present management systems in Mediterranean areas: (i) dense shrub cover (DS) (with the unaltered and original vegetation growing after land abandonment decades ago), (ii) grazing meadows (GM) (a regularly grazed field with manual annual harvest), (iii) cereal plot (C) (adding chemical fertilizers and alternating with the fallow land plot), (iv) fallow land (FL) (alternating with the cereal plot), (v) abandoned field (AF) (it was cultivated in the first year and then abandoned to initiate natural revegetation), (vi) shifting agriculture (SA) (traditionally only fertilized with ashes), (vii) abandoned shifting agriculture (ASA) (a cultivated shifting field that was abandoned after 4 years of cultivation to initiate natural revegetation), (viii) burned plot 1 (B1) (burned in 1991) and (ix) burned plot 2 (B2) (burned twice in 1993 and 2001) (Figure 2). Both burned plots were affected by plant recolonization following the fire.

In the cereal plot, chemical fertilizer was added annually with $\mathrm{N}-\mathrm{NH}_{4}\left(30 \mathrm{~kg} \mathrm{ha}^{-1}\right), \mathrm{P}_{2} \mathrm{O}_{5}$ $\left(60 \mathrm{~kg} \mathrm{ha}^{-1}\right)$ and $\mathrm{K}_{2} \mathrm{O}\left(20 \mathrm{~kg} \mathrm{ha}^{-1}\right)$ as the main constituents, with very small quantities of $\mathrm{Mg}^{2+}, \mathrm{S}$ and Fe. Given that the fallow land plot alternated yearly with the cereal plot, its soil was also enriched with chemical fertilizer each two years. The abandoned plot (previously cultivated with cereal) received similar quantities of chemical fertilizer as the cereal plot during the years it was cultivated.

In addition, 5 top soil samples (1991, non-disturbed due to experimentation) were taken spatially distributed in the slope where the AVES was located and physico-chemical analyses were made, including texture, $\mathrm{pH}$, organic matter and nitrogen, $\mathrm{CaCO}_{3}$ and $\mathrm{P}, \mathrm{K}, \mathrm{Mg}$ content. 


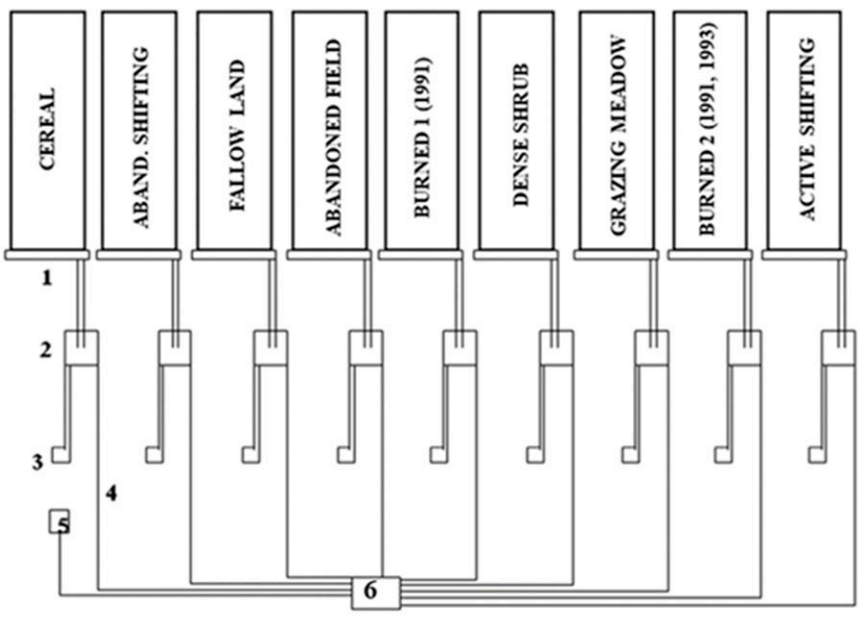

1. GERLACH CANAL; 2. TIPPING BUCKET; 3. SEDIMENT COLLECTOR; 4. CONNECTIONCABLE; 5. PLUVIOMETER; 6. DATA LOGGERS
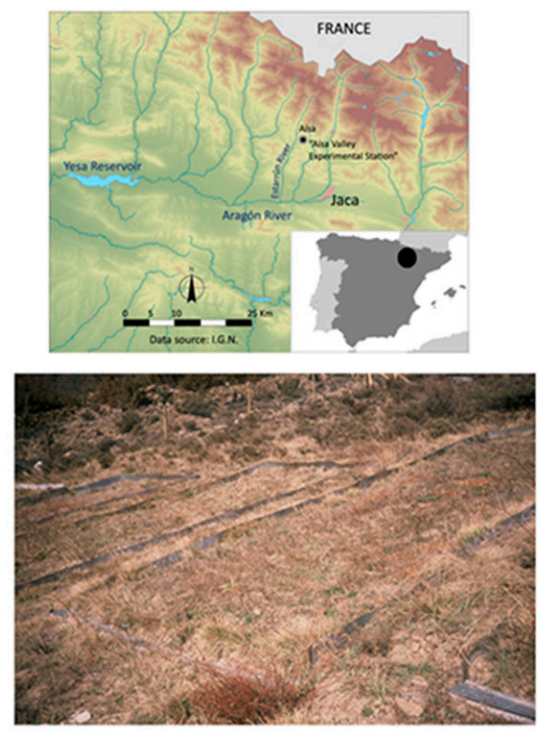

Figure 1. Study area and Aísa Valley Experimental Station scheme and overview of the station.
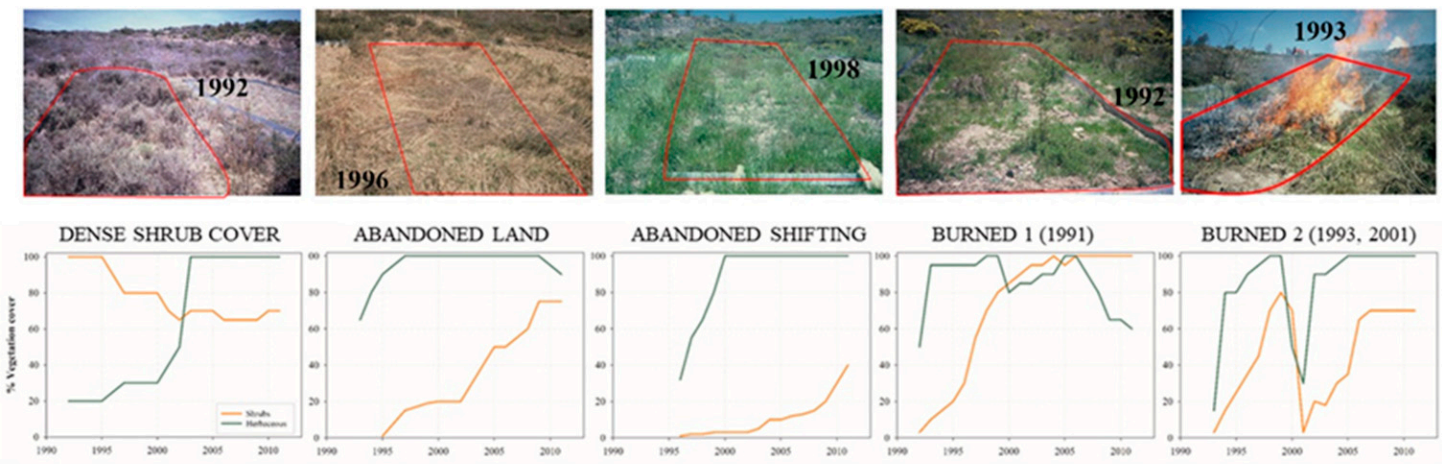

ABANDONED SHIFTING

BURNED 1 (1991)

BURNED 2 (1993, 2001)
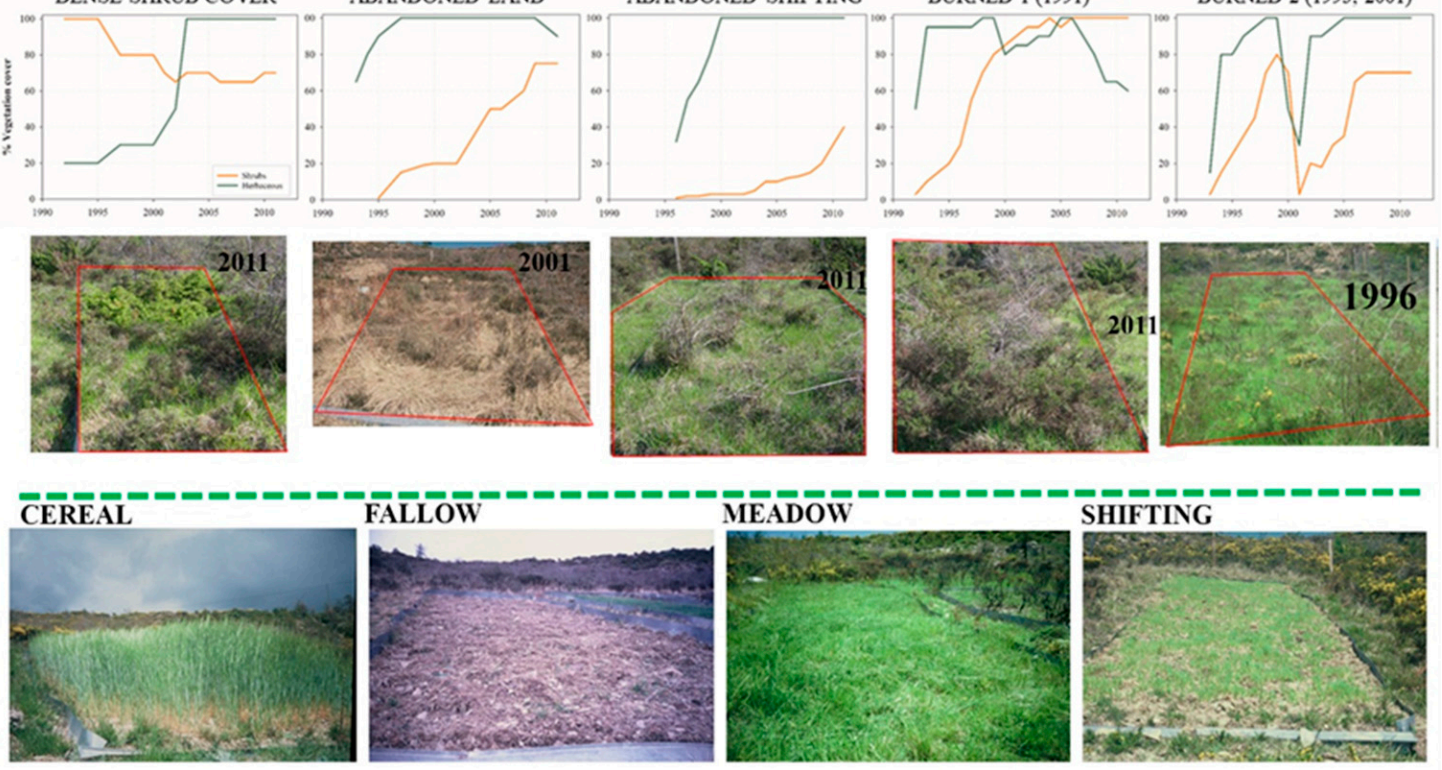

Figure 2. Plant cover evolution in the different land uses in two different stages.

\subsection{Statistical Analysis}

Data from each plot were analysed statistically to provide annual averages (mean, median and standard deviation). Likewise, box plots were used to provide a representation of the annual average solute concentration data variability.

As the assumption of normal distribution could not be met for most variables, as checked by a Shapiro-Wilk normality test, the non-parametric Kruskal-Wallis one-way analysis was used to identify which LULC differ statistically from each other. Correlations between parameters were checked and tested by the Spearman's rank correlation test. In all cases, differences were taken to be statistically significant at $p<0.05$. Principal component analysis (PCA) was also performed to determine first 
correlations among the measured variables and to elucidate major variation patterns in terms of land uses.

\section{Results}

\subsection{Soil Properties and Land Cover Evolution}

Physical and chemical soil properties were analysed in 1991 for the original hillslope where the experimental station was located (revegetated area after some decades of land abandonment) (Table 1). Grain size distributions showed a predominance of sand fraction (loam texture): 40.5\% was sand, $34.4 \%$ was silt and $25.1 \%$ was clay. Chemical soil analysis demonstrated that the soils in the study area had very poor contents of $\mathrm{P}, \mathrm{K}$ and $\mathrm{Mg}$, whilst they were abundant in $\mathrm{N}$ owing to the presence of leguminous plants (G. scorpius). Organic matter content was $2.3 \%$. Conversely, the soils showed a very high carbonate content $(32.9 \%)$ corresponding to soils developed on a calcareous substratum.

Table 1. Mean and standard deviation values of the studied soil parameters in 1991.

\begin{tabular}{cc}
\hline Soil Parameters (1991) & Mean and Standard Deviation \\
\hline $\mathrm{pH}$ & $7.9 \pm 0.3$ \\
\hline$\% \mathrm{CaCO}_{3}$ & $32.9 \pm 6.2$ \\
\hline$\% \mathrm{~N}$ & $1.8 \pm 0.7$ \\
\hline$\%$ Organic matter & $2.3 \pm 1.1$ \\
\hline $\mathrm{C} / \mathrm{N}$ ratio & $7.1 \pm 0.7$ \\
\hline $\mathrm{P}(\mathrm{ppm})$ & $4.4 \pm 3.7$ \\
\hline $\mathrm{K}(\mathrm{ppm})$ & $1.3 \pm 0.5$ \\
\hline $\mathrm{Mg}(\mathrm{ppm})$ & $0.8 \pm 0.2$ \\
\hline$\%$ Sand & $40.5 \pm 2.7$ \\
\hline$\%$ Silt & $34.4 \pm 4.9$ \\
\hline$\%$ Clay & $25.1 \pm 5.9$ \\
\hline
\end{tabular}

Figure 2 presents the evolution of plant cover in the different plots during the study period, with some remarkable results: (i) surprisingly, the dense shrub cover plot gradually evolved with open spaces due to the senescence of the shrub (together with a higher herbaceous cover) (Figure 2). In addition, partial replacement of G. scorpius by Juniperus communis was observed; (ii) the abandoned cereal plot was rapidly revegetated (first by a dense herbaceous cover and later with shrubs) and tended to be similar to that of the dense shrub cover at the end of the study period thanks to the fertilizer added when it was cultivated (Figure 2); (iii) the abandoned shifting agriculture evolved much slower than the abandoned cereal plot due to the differences observed in soil properties and fertilizers, confirming soil deterioration in slopes cultivated under slash-and-burn practices; this plot showed a rapid herbaceous recovery, although shrubs found severe problems in colonizing the plot; and (iv) in the burned plots a rapid recovery of vegetation was observed in the first few years after the fire. Interestingly, during the study period, the vegetation cover was lower in the plot burned twice (1993 and 2001) than in the plot that was burned only once in 1991 (Figure 2). In any case, the burned plot 2 also shows a positive trend in vegetation recovery after each fire. As expected, plant cover in the fallow land, meadow, cereal and shifting agriculture plots did not change throughout the study period and only changes due to vegetative cycle of the crop were observed (Figure 2).

\subsection{Runoff and Suspended Sediment Concentration Updating}

Mean annual rainfall value for the study period was $1181 \mathrm{~mm}$. Data on runoff response for the period 1996-2009 and for only 7 plots has already been presented in Nadal-Romero et al. [17]. Table 2 
presents an update of these values with data relating to the full period (1991-2011 with small variations) and 9 LULC. Concerning runoff water yielded, three groups of plots were differentiated: (i) the lowest runoff values were recorded in the dense shrub cover $\left(63.5 \mathrm{~L} \mathrm{~m}^{-2}\right)$, burned 1 (burned in 1991, with dense vegetation cover) $\left(68.4 \mathrm{~L} \mathrm{~m}^{-2}\right)$ and grazing meadow $\left(89.2 \mathrm{~L} \mathrm{~m}^{-2}\right)$ plots, (ii) moderate values were recorded in the abandoned field $\left(137.1 \mathrm{~L} \mathrm{~m}^{-2}\right)$, abandoned shifting agriculture $\left(146.2 \mathrm{~L} \mathrm{~m}^{-2}\right)$ and burned $2\left(158.3 \mathrm{~L} \mathrm{~m}^{-2}\right)$ plots; and (iii) the third group includes the plots related to agricultural activities showing the highest values: fallow land $\left(181.0 \mathrm{~L} \mathrm{~m}^{-2}\right)$, cereal $\left(237.5 \mathrm{~L} \mathrm{~m}^{-2}\right)$ and active shifting agriculture $\left(239.0 \mathrm{~L} \mathrm{~m}^{-2}\right)$ plots. Table 2 also refers to suspended sediment and solute concentration, as well as to the total sediment yields and the percentage of solutes to total sediment production. Suspended sediment concentration $\left(\mathrm{mg} \mathrm{L}^{-1}\right)$ tends to behave in a similar way to runoff, although some differences must be noted: (i) in the first group, with low values of suspended sediment concentration, the abandoned field plot $\left(37.8 \mathrm{mg} \mathrm{L}^{-1}\right)$ adds to the dense shrub cover $\left(26.5 \mathrm{mg} \mathrm{L}^{-1}\right)$, the burned 1 (28.3 $\mathrm{mg} \mathrm{L}^{-1}$ ) and the grazing meadow $\left(35.2 \mathrm{mg} \mathrm{L}^{-1}\right.$ ) plots; (ii) in the second group, the cereal plot (138.6 $\mathrm{mg} \mathrm{L}^{-1}$ ) recorded similar values to that of abandoned shifting agriculture (118.2 $\left.\mathrm{mg} \mathrm{L}^{-1}\right)$; and (iii) the third group comprises burned $2\left(151.5 \mathrm{mg} \mathrm{L}^{-1}\right)$, the active shifting agriculture $\left(223.1 \mathrm{mg} \mathrm{L}^{-1}\right)$ and the fallow land $\left(298.6 \mathrm{mg} \mathrm{L}^{-1}\right)$ plots. Information on the standard deviation for the suspended sediment concentration reveals an extremely high variability, particularly in the case of the plots with greatest erosion (fallow land and shifting agriculture plots followed by the burned plot 2).

\subsection{Solute Water Chemistry and Total Sediment Production}

Data on solute concentrations can be found in Table 2, with significant differences among LULC. In this case, the statistical analyses indicated that only two groups of land uses can be distinguished with small differences in respect of those identified for water and annual sediment production:

(i) The lowest solute concentration values were recorded in the grazing meadow (115.6 $\mathrm{mg} \mathrm{L}^{-1}$ ) and dense shrub cover (118.1 $\mathrm{mg} \mathrm{L}^{-1}$ ) plots, where agricultural activity was absent during all the study period and a dense plant cover was recorded. Mid-range values were obtained in the abandoned cereal field (133.1 $\mathrm{mg} \mathrm{L}^{-1}$ ) and the two burned plots (1 and 2) (130.6 and $136.2 \mathrm{mg} \mathrm{L}^{-1}$, respectively).

(ii) The highest values were recorded in the cereal plot $\left(192.6 \mathrm{mg} \mathrm{L}^{-1}\right)$, fallow $\left(196.1 \mathrm{mg} \mathrm{L}^{-1}\right)$ and shifting agriculture (active and abandoned) (159.7 and $181.9 \mathrm{mg} \mathrm{L}^{-1}$ respectively), where chemical fertilizer or ash were added.

The total sediment yield for the nine plots $\left(\mathrm{g} \mathrm{m}^{-2}\right)$ appear in Table 2, providing a general perspective of the influence of different LULC on sediment losses. Two groups of plots were also distinguishable: (i) the dense shrub cover plot produced the lowest mean annual sediment yield $\left(9.8 \mathrm{~g} \mathrm{~m}^{-2}\right)$, followed by burned $1\left(13.3 \mathrm{~g} \mathrm{~m}^{-2}\right)$, the grazing meadow plot $\left(16.2 \mathrm{~g} \mathrm{~m}^{-2}\right)$ and the abandoned field $\left(27.2 \mathrm{~g} \mathrm{~m}^{-2}\right)$. (ii) Intermediate yields (already two-three fold higher than the previous values) were found for the plot burned twice $\left(64.5 \mathrm{~g} \mathrm{~m}^{-2}\right)$ and the cereal plot $\left(81.6 \mathrm{~g} \mathrm{~m}^{-2}\right)$, followed by the highest yields that were found for the fallow land $\left(100.9 \mathrm{~g} \mathrm{~m}^{-2}\right)$, the abandoned shifting agriculture $\left(102.7 \mathrm{~g} \mathrm{~m}^{-2}\right)$ and the active shifting agriculture $\left(143.8 \mathrm{~g} \mathrm{~m}^{-2}\right)$ plots. The proportion of solutes in relation to the total sediment output varied significantly, showing that plots with low values of sediment exportation have a greater loss of solutes than those of suspended sediment: dense shrub cover, grazing meadow, abandoned field and burned plot 1 , where solutes represent more than $63 \%$ of the total sediment outputs. 
Table 2. Mean values and standard deviations of runoff, suspended sediment concentration, solute concentration, total sediment and \% of solutes for the period of 1991-2011 (except for abandoned field whose data are from 1992-2011, burned 2 whose data are from 1993-2011 and abandoned shifting agriculture whose data are from 1995-2011). Means with the different lower-case letter within a column are significantly different at the 0.05 level of significance $(p<0.05)$.

\begin{tabular}{|c|c|c|c|c|c|}
\hline & $\begin{array}{l}\text { Annual Runoff } \\
\left(\mathrm{L} \mathrm{m}^{-2}\right)\end{array}$ & $\begin{array}{c}\text { Suspended Sediment } \\
\text { Concentration } \\
\left(\mathrm{mg} \mathrm{L}^{-1}\right)\end{array}$ & $\begin{array}{l}\text { Solute Concentration } \\
\qquad\left(\mathrm{mg} \mathrm{L}^{-1}\right)\end{array}$ & $\begin{array}{c}\text { Total Annual Sediment } \\
\qquad\left(\mathrm{g} \mathrm{m}^{-2}\right)\end{array}$ & $\%$ Solutes \\
\hline Dense shrub cover & $63.5 \pm 32.0(a)$ & $26.5 \pm 24.1(\mathrm{a})$ & $118.1 \pm 27.9$ (a) & $9.8 \pm 5.63(\mathrm{a})$ & 72.1 (a) \\
\hline Burned 1 (1991) & $68.4 \pm 28.9(a)$ & $28.3 \pm 39.5(\mathrm{a})$ & $130.6 \pm 27.5(\mathrm{a})$ & $13.3 \pm 6.08(a)$ & 70.1 (a) \\
\hline Grazing meadow & $89.2 \pm 47.4(\mathrm{a})$ & $35.2 \pm 41.3(\mathrm{a})$ & $115.6 \pm 33.8(\mathrm{a})$ & $16.2 \pm 7.55(\mathrm{a})$ & $63.4(\mathrm{a})$ \\
\hline Abandoned field & $137.1 \pm 62.0(\mathrm{~b})$ & $37.8 \pm 37.6(a)$ & $133.1 \pm 33.3(\mathrm{a})$ & $27.2 \pm 13.31$ (a) & $63.0(\mathrm{a})$ \\
\hline Burned 2 (1993-2001) & $158.3 \pm 88.4(\mathrm{bc})$ & $151.5 \pm 221.0(\mathrm{bc})$ & $136.2 \pm 43.0(\mathrm{a})$ & $64.5 \pm 46.37(\mathrm{~b})$ & $31.3(b)$ \\
\hline Cereal & $237.5 \pm 205.9(\mathrm{c})$ & $138.6 \pm 118.5(b)$ & $192.6 \pm 52.0(\mathrm{~b})$ & $81.6 \pm 51.54(\mathrm{~b})$ & $40.0(\mathrm{~b})$ \\
\hline Fallow land & $181.0 \pm 109.9(\mathrm{bc})$ & $298.6 \pm 398.4(\mathrm{c})$ & $196.1 \pm 41.1(\mathrm{~b})$ & $100.9 \pm 79.26(b)$ & $29.2(b)$ \\
\hline Abandoned shifting agriculture & $146.2 \pm 100.9(\mathrm{bc})$ & $118.2 \pm 93.3(b)$ & $159.7 \pm 24.7(b)$ & $102.7 \pm 114.5(b)$ & $22.4(\mathrm{~b})$ \\
\hline Active shifting agriculture & $239.0 \pm 143.8(\mathrm{c})$ & $223.1 \pm 298.9(\mathrm{bc})$ & $181.9 \pm 26.6(b)$ & $143.8 \pm 122.7(b)$ & $29.1(b)$ \\
\hline
\end{tabular}


Table 3. Spearman Correlations between $\mathrm{pH}$ and electrical conductivity (EC) and a set of relevant elements of water $\left(p<0.05^{*} ; p<0.01^{* *}\right)$.

\begin{tabular}{|c|c|c|c|c|c|c|c|c|c|c|c|c|c|c|}
\hline & $\mathrm{pH}$ & $\mathrm{CE}$ & $\mathrm{HCO}_{3}^{-}$ & $\mathrm{Cl}$ & $\mathrm{SO}_{4}{ }^{2-}$ & $\mathrm{Ca}^{2+}$ & $\mathrm{Mg}^{2+}$ & $\mathrm{Na}^{+}$ & $\mathrm{K}^{+}$ & $\mathrm{PO}_{4}{ }^{3-}$ & $\mathrm{N}-\mathrm{NO}_{3}{ }^{-}$ & $\mathrm{N}-\mathrm{NO}_{2}{ }^{-}$ & $\mathrm{N}-\mathrm{NH}_{4}{ }^{+}$ & $\mathrm{SiO}_{2}$ \\
\hline \multicolumn{15}{|l|}{$\mathrm{pH}$} \\
\hline $\mathrm{CE}$ & $0.169 *$ & & & & & & & & & & & & & \\
\hline $\mathrm{HCO}_{3}^{-}$ & $0.464^{* *}$ & $0.641^{* *}$ & & & & & & & & & & & & \\
\hline $\mathrm{Cl}$ & -0.280 ** & $0.418^{* *}$ & $-0.193 * *$ & & & & & & & & & & & \\
\hline $\mathrm{SO}_{4}{ }^{2-}$ & $-0.366^{* *}$ & $0.357^{* *}$ & $0.445^{* *}$ & 0.008 & & & & & & & & & & \\
\hline $\mathrm{Ca}^{2+}$ & 0.047 & $0.675^{* *}$ & $0.514^{* *}$ & 0.131 & $0.266^{*}$ & & & & & & & & & \\
\hline $\mathrm{Mg}^{2+}$ & 0.085 & $0.686^{* *}$ & $0.457^{* *}$ & $0.354^{* *}$ & $0.330^{* *}$ & $0.544^{* *}$ & & & & & & & & \\
\hline $\mathrm{Na}^{+}$ & 0.050 & $0.589 * *$ & $0.343^{* *}$ & $0.325^{* *}$ & $0.542^{* *}$ & $0.454^{* *}$ & $0.464^{* *}$ & & & & & & & \\
\hline $\mathrm{K}^{+}$ & $-0.194^{* *}$ & 0.121 & 0.002 & $0.247^{* *}$ & 0.116 & 0.028 & 0.134 & $0.179 *$ & & & & & & \\
\hline $\mathrm{PO}_{4}{ }^{3-}$ & 0.030 & 0.104 & 0.077 & 0.021 & 0.092 & 0.081 & 0.027 & 0.009 & 0.115 & & & & & \\
\hline $\mathrm{N}-\mathrm{NO}_{3}{ }^{-}$ & $0.188^{*}$ & -0.035 & 0.076 & -0.003 & $0.302 * *$ & -0.0115 & -0.036 & -0.044 & $0.166^{*}$ & $0.329^{* *}$ & & & & \\
\hline $\mathrm{N}-\mathrm{NO}_{2}{ }^{-}$ & 0.118 & 0.072 & 0.137 & 0.035 & $0.213^{* *}$ & 0.027 & 0.039 & 0.072 & $0.148^{*}$ & -0.066 & $0.402 * *$ & & & \\
\hline $\mathrm{N}-\mathrm{NH}_{4}{ }^{-}$ & -0.072 & 0.013 & -0.024 & -0.004 & -0.040 & 0.039 & -0.024 & -0.100 & -0.009 & -0.018 & 0.115 & $0.521^{* *}$ & & \\
\hline $\mathrm{SiO}_{2}$ & -0.069 & $-0.278^{* *}$ & $-0.214^{* *}$ & $-0.349^{* *}$ & $-0.325^{* *}$ & 0.104 & -0.219 & $-0.289 * *$ & -0.042 & $0.195^{* *}$ & $-0.205^{* *}$ & $-0.270^{* *}$ & -0.048 & \\
\hline
\end{tabular}


Finally, Table 2 also shows that there is more variability (higher standard deviations) in the case of suspended sediment concentrations than in solutes.

Table 3 presents the relationship among chemical water variables and solute concentrations. Concentrations of cations were, in general, positively related to each other. Negative correlations were found between $\mathrm{HCO}_{3}{ }^{-}$and $\mathrm{Cl}^{-}$concentrations and $\mathrm{SIO}_{2}$ and electrical conductivity, $\mathrm{HCO}_{3}{ }^{-}, \mathrm{Cl}^{-}$, $\mathrm{SO}_{4}{ }^{2-}, \mathrm{Na}^{+}, \mathrm{PO}_{4}{ }^{3-}, \mathrm{N}-\mathrm{NO}_{3}{ }^{-}$and N-NO${ }_{2}^{-}$. No statistical correlations were found between $\mathrm{Cl}^{-}$and $\mathrm{SO}_{4}{ }^{2-}$ concentrations. In addition, significant correlation between $\mathrm{N}^{-N_{O}}{ }_{3}^{-}$and $\mathrm{SO}_{4}{ }^{2-}$ was observed.

Figure 3 presents box plots to summarize water quality responses at the nine LULC (solute concentration, $\mathrm{mg} \mathrm{L}^{-1}$ ) and Table 4 informs on the total losses of the most representative solutes for each LULC $\left(\mathrm{g} \mathrm{m}^{-2}\right)$. The most significant solute outputs were in the form of $\mathrm{HCO}_{3}{ }^{-}$, with losses close to $20 \mathrm{~g} \mathrm{~m}^{-2}$ from cereal, shifting agriculture and fallow land. Obviously $\mathrm{Ca}^{2+}$ was also carried out in high quantities (values between $5-8.5 \mathrm{~g} \mathrm{~m}^{-2}$ in the same plots cited above), while the rest of solutes showed lower values, especially $\mathrm{Na}^{+}$and $\mathrm{Mg}^{2+}$ (due to the low content in the soil). Figure 4 illustrated the $\mathrm{Ca}^{2+}-\mathrm{HCO}_{3}{ }^{-}$dominance of the solute losses. It is noteworthy that in the LULC generally affected by low solute outputs (dense shrub cover, grazing meadow, abandoned field and abandoned shifting agricultural plots) $\mathrm{HCO}_{3}{ }^{-}$represents more than $90 \%$ of total anions exported (see Figure 4).

Annual outputs of each of the solutes were significantly higher from the cereal, fallow land and shifting agriculture plots than from the other LULC (Table 4). For example, the production of $\mathrm{HCO}_{3}^{-}$, was 3-fold higher in traditional and current agricultural uses than in dense shrub cover and grazing meadows. Similar differences were recorded in most of the solute export rates. Annual yield from vegetated plots (dense shrub cover and grazing meadow) was very low.

The relative contributions of dissolved inorganic nitrogen forms (Figure 5) differed among the LULC, with $\mathrm{N}-\mathrm{NO}_{3}{ }^{-}$being predominant in all land uses (concentrations in $\mathrm{N}^{-} \mathrm{NO}_{3}{ }^{-}$were one order of magnitude higher than in the other nitrogen forms). Lower values were measured in the shifting agriculture and vegetated plots and the average yield was double in cereal and fallow land than in the other land uses. The most important result is that outputs of inorganic nitrogen forms are higher in the plots with active agriculture. Moreover, $\mathrm{N}_{-} \mathrm{NH}_{4}{ }^{+}$is mainly yielded from the abandoned shifting agriculture and the burned plot 2s. The cereal and fallow land plots, as well as the burned plot 2, also lost relatively high quantities of organic phosphorous, particularly compared with the dense shrub cover, the grazing meadow and the active shifting agriculture plots.

To confirm and summarize all this information, a principal component analysis (PCA) was carried out with all the values related to solute concentrations (runoff, $\mathrm{pH}, \mathrm{CE}$, cations, anions and nitrogen forms). Figure 6 shows a plot of the eigenvector in the plane of the first two components together with the PC scores in the plane of PC1 and PC2. On the first component, which explained $21.686 \%$ of the variance, $\mathrm{CE}$, runoff and all the cations and anions are positive. The second component explained $12.846 \%$ of the variance: it has large positive eigenvector values mainly for the main nitrogen forms and $\mathrm{pH}$. The different LULC were successfully distinguished in the plane of PC1 and PC2: (i) dense shrub cover and grazing meadow plots (both located in the negative side of the components) and moderate plots: the two burned plots and the abandoned field plot; and (ii) conversely, the cereal and fallow plots were located in the positive side of the components, close to the active and abandoned shifting agriculture plots (indicating high values). 

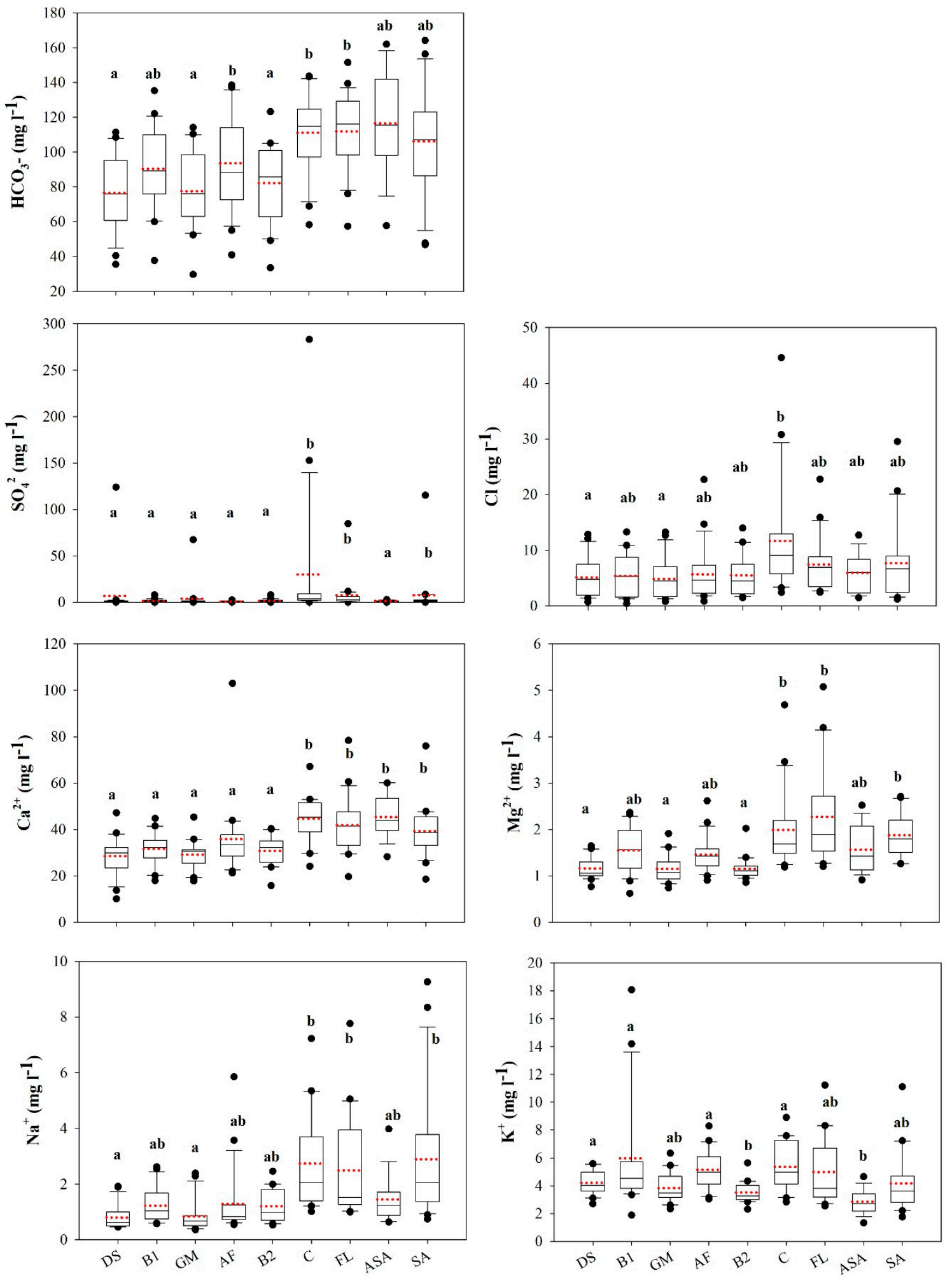

Figure 3. Solute concentrations $\left(\mathrm{mg} \mathrm{L}^{-1}\right.$ ) from various land uses for the period 1991-2011 (red dotted line: mean value; black line: median values; black points: outliers; borders of the box are 25 and 75 percentiles; and borders of the box plot are the 10 and 90 percentiles). DS: Dense shrub cover; B1: burned plot 1; GM: grazing meadows; AF: abandoned field; B2: burned plot 2; C: Cereal; FL: fallow land; ASA: abandoned shifting agriculture; AS: active shifting. Means with the different lower-case letter within are significantly different at the 0.05 level of significance $(p<0.05)$. 
Table 4. Mean and standard deviations of solute losses $\left(\mathrm{g} \mathrm{m}^{-2}\right)$ for the period 1991-2011 (except for abandoned field whose data are from 1992-2011, burned 2 whose data are from 1993-2011 and abandoned shifting agriculture whose data are from 1995-2011). Means with the different lower-case letter within a column are significantly different at the 0.05 level of significance $(p<0.05)$.

\begin{tabular}{|c|c|c|c|c|c|c|c|}
\hline & $\mathrm{HCO}_{3}^{-}$ & $\mathrm{Cl}^{-}$ & $\mathrm{SO}_{4}{ }^{2-}$ & $\mathrm{Ca}^{2+}$ & $\mathrm{Mg}^{2+}$ & $\mathrm{Na}^{+}$ & $\mathrm{K}^{+}$ \\
\hline Dense shrub cover & $4.6 \pm 2.7(\mathrm{a})$ & $0.3 \pm 0.2(\mathrm{a})$ & $0.1 \pm 0.2(\mathrm{a})$ & $1.7 \pm 1(\mathrm{a})$ & $0.1 \pm 0.04(\mathrm{a})$ & $0.04 \pm 0.03(\mathrm{a})$ & $0.3 \pm 0.2(\mathrm{a})$ \\
\hline Burned 1 (1991) & $6.3 \pm 3.0(\mathrm{ab})$ & $0.1 \pm 0.3(\mathrm{ab})$ & $0.2 \pm 2.0(\mathrm{a})$ & $2.2 \pm 1.0(\mathrm{a})$ & $0.1 \pm 0.1(\mathrm{ab})$ & $0.1 \pm 0.1(a b)$ & $0.4 \pm 0.3(\mathrm{a})$ \\
\hline Grazing meadow & $6.6 \pm 3.0(a)$ & $0.4 \pm 0.4(\mathrm{a})$ & $0.2 \pm 0.8(\mathrm{a})$ & $2.6 \pm 1.1(\mathrm{a})$ & $0.1 \pm 0.1(\mathrm{a})$ & $0.07 \pm 0.03(\mathrm{a})$ & $0.3 \pm 0.2(a b)$ \\
\hline Abandoned field & $12.3 \pm 6.6(\mathrm{ab})$ & $0.7 \pm 0.6(\mathrm{ab})$ & $0.1 \pm 0.1(\mathrm{a})$ & $5.0 \pm 4.0(\mathrm{a})$ & $0.2 \pm 0.1(\mathrm{ab})$ & $0.1 \pm 0.1(\mathrm{ab})$ & $0.7 \pm 0.4(\mathrm{a})$ \\
\hline Burned 2 (1993-2001) & $14.2 \pm 9.9(\mathrm{a})$ & $0.9 \pm 0.8(\mathrm{ab})$ & $0.1 \pm 0.8(\mathrm{a})$ & $5.2 \pm 3.2(\mathrm{a})$ & $0.2 \pm 0.1(\mathrm{a})$ & $0.2 \pm 0.2(\mathrm{ab})$ & $0.6 \pm 0.3(b)$ \\
\hline Cereal & $19.2 \pm 9.5(b)$ & $1.8 \pm 1.1(b)$ & $2.3 \pm 5.2(b)$ & $7.8 \pm 3.3(b)$ & $0.4 \pm 0.3(b)$ & $0.5 \pm 0.3(b)$ & $0.9 \pm 0.5(a)$ \\
\hline Fallow land & $17.1 \pm 10.5(b)$ & $1.3 \pm 1.0(\mathrm{ab})$ & $0.8 \pm 1.8(b)$ & $6.5 \pm 3.6(b)$ & $0.4 \pm 0.3(b)$ & $0.5 \pm 0.5(b)$ & $0.7 \pm 0.5(\mathrm{ab})$ \\
\hline Abandoned shifting agriculture & $14.2 \pm 7.6(\mathrm{ab})$ & $0.7 \pm 0.6(\mathrm{ab})$ & $0.1 \pm 0.2(\mathrm{a})$ & $5.6 \pm 3.5(b)$ & $0.3 \pm 0.2(\mathrm{ab})$ & $0.2 \pm 0.1(\mathrm{ab})$ & $0.4 \pm 0.3(b)$ \\
\hline Active shifting agriculture & $23.7 \pm 16.0(\mathrm{ab})$ & $2.0 \pm 2.0(\mathrm{ab})$ & $0.5 \pm 0.8(\mathrm{ab})$ & $8.5 \pm 5.2(b)$ & $0.4 \pm 0.2(\mathrm{~b})$ & $0.7 \pm 0.8(b)$ & $1.0 \pm 0.8(\mathrm{ab})$ \\
\hline
\end{tabular}



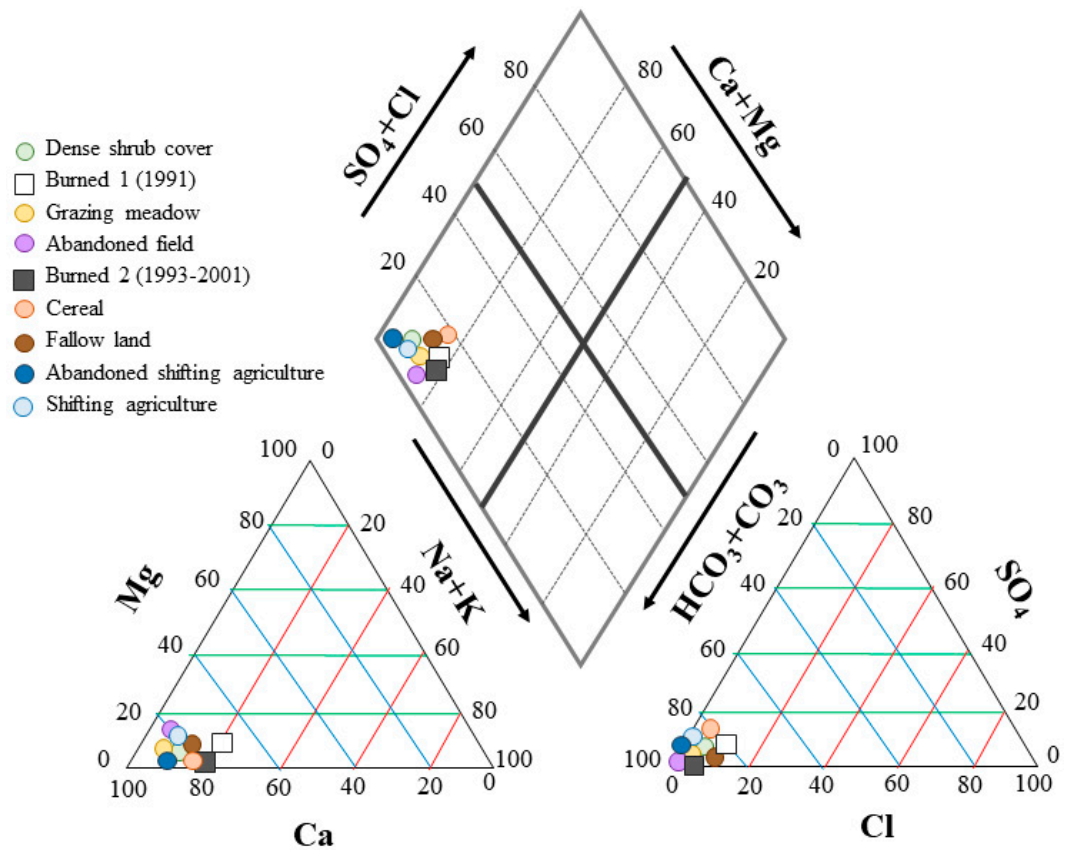

Figure 4. Piper diagram with mean solute losses from various land uses for the period 1991-2011.
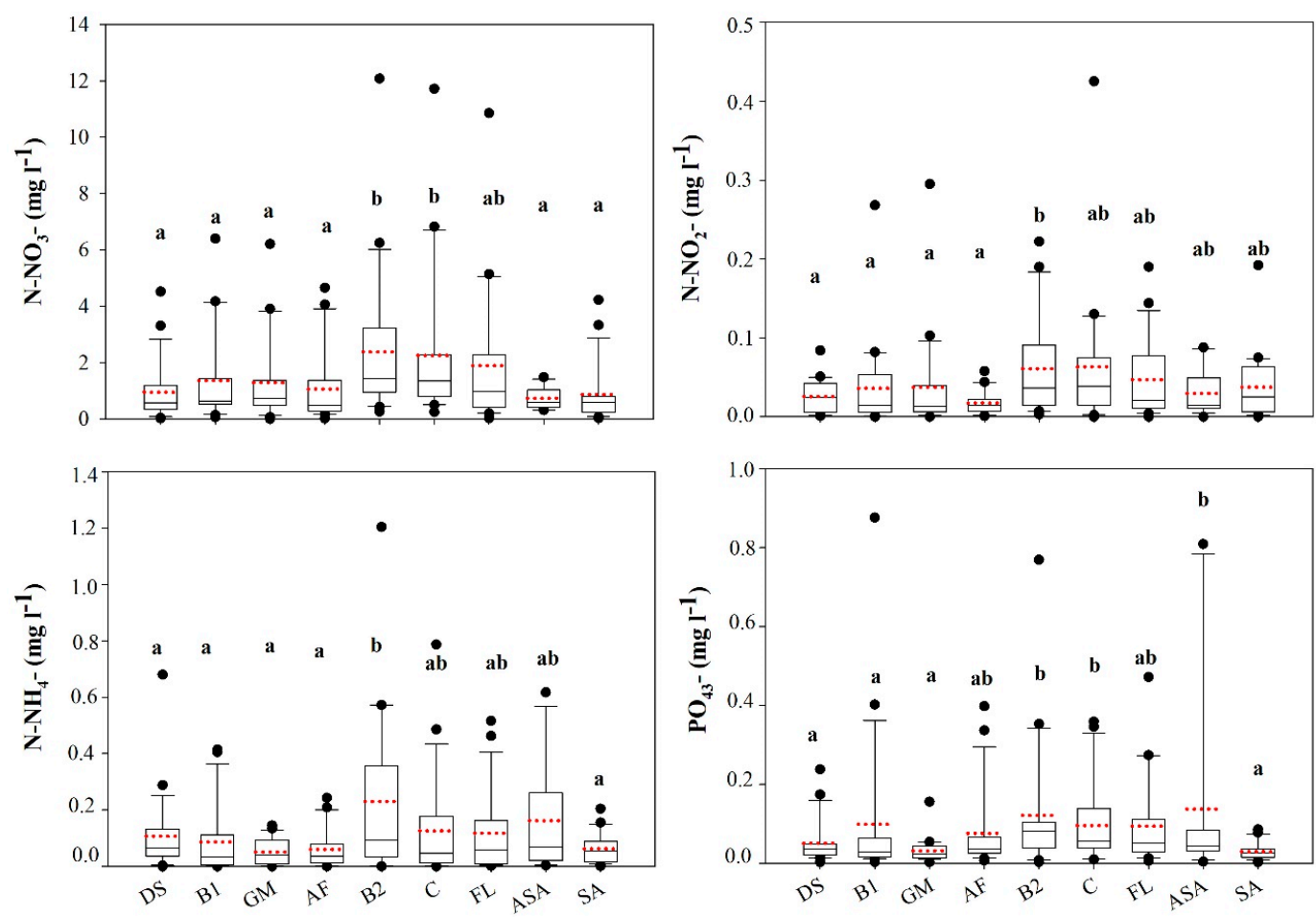

Figure 5. Nitrogen and phosphorus concentrations $\left(\mathrm{mg} \mathrm{L}^{-1}\right)$ from various land uses for the period 1991-2011 (red dotted line: mean value; black line: median values; black points: outliers; borders of the box are 25 and 75 percentiles; and borders of the box plot are the 10 and 90 percentiles). DS: Dense shrub cover; B1: burned plot 1; GM: grazing meadows; AF: abandoned field; B2: burned plot 2; C: Cereal; FL: fallow land; ASA: abandoned shifting agriculture; AS: active shifting. Means with the different lower-case letter within are significantly different at the 0.05 level of significance $(p<0.05)$. 


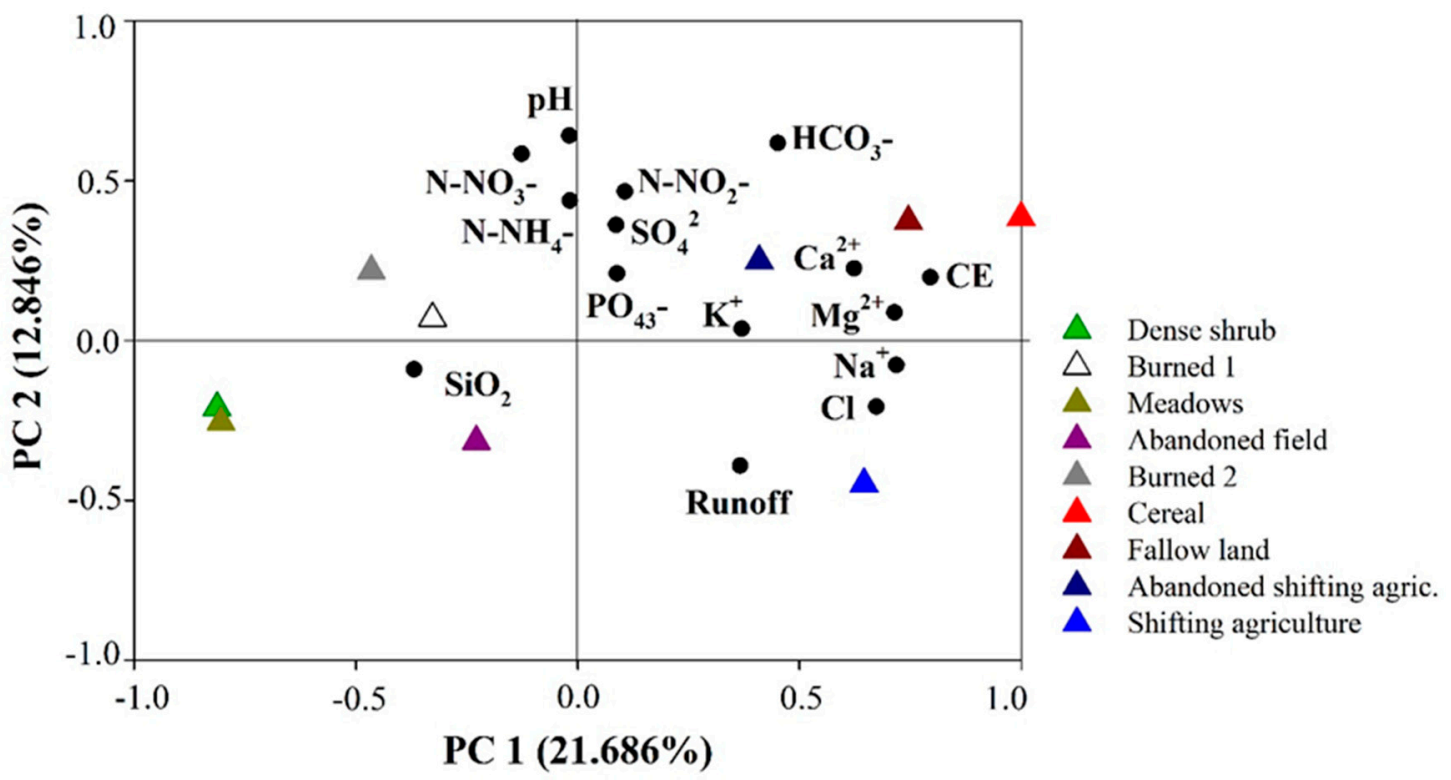

Figure 6. Eigenvectors from the principal component analysis (PCA) and PC scores plotted in the plane of the first two components.

\section{Discussion}

This study confirms the hypothesis that different LULC conditioned runoff erosion and solute concentration and yield. Nevertheless, it should be highlighted that the use of experimental plots for estimating runoff, suspended sediment and solutes has many limitations [48]. In our study, the characteristics of the plots, especially the size $\left(30 \mathrm{~m}^{2}\right)$, limit the validity of the data (since within-ground water cannot be included). A different limitation is related to the sediment exhaustion due to the system of closed plots. Although this fact has not been analysed in the study, Nadal-Romero et al. [17] observed a negative trend in sediment yield in some plots suggesting that sediment exhaustion occurred several years after initiation of the experiment. This negative trend in some cases could be related to vegetation recovery (followed by a stabilization) but in other cases (as cereal and fallow land) a clear decrease is observed during the first years of study, suggesting sediment exhaustion related to the specific conditions of the station. For this reason, the authors considered to terminate the experiment avoiding the analysis of the last two years on the database. Nevertheless, the plots enable different LULC to be studied individually and the results are good indicators of the relative differences among these LULC for comparative purposes. Likewise, our results are consistent with other studies in the Mediterranean region carried out at catchment scale [41,46].

Previous studies in this experimental station already confirmed that LULC controls runoff and suspended sediment production [17]. In the case of solute concentrations and loads, the results obtained in this study demonstrate that there are highly significant differences between the LULC with little soil and plant cover disturbances (i.e., dense shrub cover or grazing meadows) and those greatly disturbed by human activities (i.e., cereal or shifting agriculture). In the AVES, the agriculture plots (cereal, fallow and shifting agriculture) produced significantly higher solute concentrations than vegetated areas. These results are in line with previously published studies [37,39,45]. Risking et al. [49] indicated that intensive cropland agriculture commonly increases water solute concentrations and export rates. Other authors have also reported higher concentrations in agricultural than in non-agricultural areas under similar geological and climatological conditions [46]. Indeed, agriculture is a major source of contamination for water bodies worldwide (i.e., [50]) due to the use of nutrients (most studies only focus on $\mathrm{N}$ and $\mathrm{P}$ ), agrochemicals and the agricultural activity, increasing runoff production, erosion rates and the export of solutes and changing water chemistry. Moreover, the removal (ploughing) of 
the soil year by year in the agricultural plots causes the renewal of surface soil characteristics and, as a consequence, new nutrients are available to be carried out of the plot.

It is also interesting to note the solute behaviour observed in the burned plots. Numerous studies evaluating the effects of fire on solute losses have been published in the last decades (e.g., [51-53]), all of which confirmed that solute losses were much higher on burned areas compared with dense shrub cover, although these differences can be limited to the first two months after the fire (i.e., [54]). Our results, indicated that these differences in the long-term have been declining in the plot burned once in 1991 (recover with vegetation) and that major differences exist in the case of the plot burned twice (in 1993 and 2001), suggesting that the high occurrence of fires hampers the recovery of a dense shrub cover, producing higher losses of suspended and solute sediments. In that respect, Ruiz-Flaño et al. [55] indicated that fire reiterations, to remove shrublands and regenerate pasturelands in the Pyrenees, caused the loss of the fertile soil layer due to soil erosion and increased rock cover on the soil's surface.

The results of our study highlight that runoff volumes and soil losses are low in uncultivated plots, due to the high vegetation cover (see Figure 2). It is well known that vegetation reduces surface runoff and soil erosion (due to the protection to splash) and indirectly improves soil quality (increasing fertility, porosity and the number and stability of the aggregates) which favours water infiltration and decreases surface runoff $[12,17,43]$. Nevertheless, it should be remembered that plant succession after land abandonment is often a very slow process due to low rainfall values, soil depletion during the cultivation period [56] or human disturbances after land abandonment (overgrazing and fires) [55]. In these cases, soil losses are very high due to soil erosion processes (rills, gullies), producing an irreversible period of soil degradation, which is only possible to solve with expensive restorations measures [57].

In this study, carbonate dissolution is relevant for water chemistry in all land uses, as illustrated by the dominance of $\mathrm{Ca}^{2+}$ and $\mathrm{HCO}_{3}{ }^{-}$outputs (Figure 4). This result is related to the lithology of the study area (Eocene Flysch), dominated by carbonate rocks and is consistent with other studies in mainly limestone catchments (i.e., [58]). In fact, Walling \& Webb [59] noted that $\mathrm{Ca}^{2+}$ and $\mathrm{HCO}_{3}{ }^{-}$represent the prevailing cations and anions in most waters of the world (see also [60]). Notwithstanding, one of the most relevant results is that the proportion of $\mathrm{Ca}^{2+}$ and $\mathrm{HCO}_{3}{ }^{-}$greatly increases in the runoff of the lower exporting LULC, thus demonstrating that the most important soil nutrients $\left(\mathrm{Mg}^{2+}, \mathrm{K}^{+}, \mathrm{Na}^{+}\right)$ are strongly controlled by dense shrub cover (dense shrub and abandoned field plots) and grazed grasslands. Furthermore, the relative contributions of dissolved inorganic nitrogen forms differ among LULC, with $\mathrm{N}-\mathrm{NO}_{3}$ being the predominant inorganic nitrogen forms in all land uses, especially in agricultural plots because of the addition of chemical fertilizer, the factor that also explains the losses of organic phosphorous. In any case, the higher presence of phosphorous within the solute outputs in the LULC particularly affected by soil erosion is probably due to the prevailing sheet wash erosion recorded in the experimental plots, since phosphates are strongly attached to soil particles and are carried away with them by overland flow. In fact, soil analyses performed in the same study area by Ruiz-Flaño [61] demonstrated that soil samples taken from the lower part of the fields have a higher $P$ content than those taken from the upper part. This result is also consistent with those obtained in other studies (i.e., [62]).

Standard deviations illustrate the distinct behaviour of solutes and suspended sediment. The former shows very low standard deviations, much lower than those from suspended sediment. This suggests that solutes are always present in the runoff with similar values, regardless of the volume of overland flow, whereas suspended sediment is affected by extremely high variability, given its close dependency on the intensity and volume of precipitation and runoff. Furthermore, the small range in the values of solute concentration than in suspended sediment concentration (Table 2) also suggests the limitations of experimental plots to study solute outputs, since they do not record the decisive effect of rainfall infiltration within the soil; therefore, only the effects of soil surface dissolution processes are included, so that the differences in solute concentration among LULC are relatively low. 


\section{Implications for Land Management}

Both suspended and solute concentrations, as well as the total outputs, provide relevant information for land management in degraded areas with steep land. The analysis of suspended sediment yield from the AVES reveals that cultivation of steep slopes contributes heavily to soil erosion, with higher soil losses from the cereal, fallow land and active shifting agriculture plots $[17,56,63]$. In particular, shifting agriculture yielded very high quantities of suspended sediment, explaining why a stone paving completely covered the soil surface in the areas that were cultivated in the past with slash-and-burn practices and the general landscape disturbance in the most marginal mountain areas $[62,64]$. Conversely, sediment yield from scarcely disturbed areas showed very low erosion rates. These results roughly coincide with the solute losses presented in this study, with a progressive gradation from the less disturbed plots to the cereal and fallow land plots, confirming that annual ploughing and fertilizing are critical factors for solute losses. Those plots that were disturbed in the past and now are affected by plant colonization (burned 1 and abandoned field plots) also show relatively low solute losses, followed by burned plot 2 , indicating the positive effects of a dense herbaceous and shrub cover. The burned plot 2 shows a high suspended sediment concentration in the long term (due to the double occurrence of fires), although the progressive plant recovery following the fires and the absence of soil removal tend to record relatively low solute concentrations.

For land management purposes, the results obtained recommend (i) avoiding cultivation on steep slopes and encouraging the abandonment of farmland to enhance recolonization of the soil with herbs and shrubs; this is particularly important in the case of shifting agriculture; (ii) promoting the presence of dense shrub or tree cover in order to control runoff and solute and suspended sediment concentrations; (iii) promoting clearing of gentle and concave hillslopes in order to generate high quality water resources and create a complex mosaic with alternating grazing meadows and shrub areas, enabling extensive stockbreeding and landscape heterogeneity; and (iv) avoiding recurrent fires that contribute to temporarily increase solute and suspended sediment losses and deteriorate the capacity of soils for rapid plant recolonization [65]. These results, together with others on various spatial scales, should help to program land abandonment in areas where cropland withdrawal is expected in the coming decades [66].

\section{Conclusions}

Runoff water, suspended sediment and solute concentration and loads were monitored in the AVES in nine $30 \mathrm{~m}^{2}$ experimental plots that represent distinct LULC over a 20-year study period (1991-2011). The results confirm the hypothesis that solute concentrations and loads from traditional and present-day agricultural activities is greater than from dense vegetated areas: dense shrub cover and grazing meadows clearly reduce runoff, sediment yield and solute concentrations and loads. The contrary occurs with agricultural activities (cereal fields, fallow land and shifting agriculture). In addition, the results indicate that the plot burned only once presents high solute losses in the short-term, due to the rapid recovery of vegetation, whereas the plot burned twice showed higher solute loads during the whole study period.

Significant differences among LULC were observed and two groups have been identified related to solute concentration and total sediment yield: (i) in the first group, dense shrub cover, grazing meadow, the plot burned once several years ago (and at present densely colonized with shrubs) and abandoned field record the lowest solute concentrations and export small quantities of dissolved solids and sediment; and (ii) in an intermediate position, the plot burned twice several years ago registered moderate values due to the positive influence of relatively rapid plant colonization and cereal, fallow land and both shifting agriculture (active and abandoned) plots record the highest solute concentrations and yield large quantities of solutes, because of ploughing and poor plant cover. Thus, for solute concentration the ranking of LULC ranges from the less disturbed plots to those where cropping is still fully functioning. These results confirm that farmland abandonment represents a 
decrease in solute outputs (as in suspended sediment) in areas of steep land and that abandoned fields tend to record similar values to those with dense shrub cover.

Author Contributions: Conceptualization, T.L. and J.M.G.-R.; methodology, T.L., J.M.G.-R., E.N.-R.; formal analysis, E.N.-R.; investigation, E.N.-R., M.K., T.L., J.M.G.-R.; resources, T.L., J.M.G.-R., E.N.-R.; data curation, E.N.-R.; writing—original draft preparation, E.N.-R., T.L., J.M.G.-R.; writing—review and editing, E.N.-R., M.K., T.L., J.M.G.-R.; visualization, E.N.-R., M.K.; supervision, T.L. and J.M.G.-R.; project administration, T.L. and J.M.G.-R.; funding acquisition, T.L. and J.M.G.-R.

Funding: This research was supported by the ESPAS project (CGL2015-65569-R, funded by the MINECO-FEDER). The "Geomorphology and Global Change" (E02_17E) research group was financed by the Aragón Government and the European Social Fund (ESF-FSE). Makki Khorchani is working with an FPI contract (BES-2016-077992) from the Spanish Ministry of Economy and Competitiveness associated to the ESPAS project.

Conflicts of Interest: The authors declare no conflict of interest.

\section{References}

1. Geissen, V.; Mol, H.; Klumpp, E.; Umlauf, G.; Nadal, M.; van der Ploeg, M.; van de Zee, S.E.; Ritsema, C.J. Emerging pollutants in the environment: A challenge for water resource management. Int. Soil Water Conserv. Res. 2015, 3, 57-65. [CrossRef]

2. Viviroli, D.; Dürr, H.H.; Messerli, B.; Meybeck, M.; Weingartner, R. Mountains of the world-water towers for humanity: Typology, mapping and global significance. Water Resour. Res. 2007, 43, W07447. [CrossRef]

3. De Jong, C.; Lawler, D.; Essery, R. Mountain hydroclimatology and snow seasonality and hydrological change in mountain environments. Hydrol. Process 2009, 23, 955-961. [CrossRef]

4. Kilic, S.; Evrendilek, F.; Berberoglu, S.; Demirkesen, A.C. Environmental monitoring of land-use and land-cover changes in a Mediterranean Region of Turkey. Environ. Monit. Assess. 2006, 114, 157-168. [CrossRef]

5. Rico-Amorós, A.M.; Olcina-Cantos, J.; Saurí, D. Tourist land use patterns and water demand: Evidence from the Western Mediterranean. Land Use Pol. 2009, 26, 493-501. [CrossRef]

6. Jlassi, W.; Nadal-Romero, E.; García-Ruiz, J.M. Modernization of new irrigated lands in a scenario of increasing water scarcity: From large reservoirs to small ponds. Cuad. Investig. Geogr. 2016, 42, 233-259. [CrossRef]

7. García-Ruiz, J.M.; López-Moreno, J.I.; Vicente-Serrano, S.M.; Lasanta, T.; Beguería, S. Mediterranean water resources in a global change. Earth Sci. Rev. 2011, 105, 121-139. [CrossRef]

8. Giorgi, F. Climate change hot-spots. Geophys. Res. Lett. 2006, 33, L08707. [CrossRef]

9. López-Moreno, J.I. Recent variations of snowpack depth in the Central Spanish Pyrenees. Arct. Antarct. Alp. Res. 2005, 37, 253-260. [CrossRef]

10. Nogués-Bravo, D.; Lasanta, T.; López-Moreno, J.I.; Araújo, M.B. Climate warming in Mediterranean mountains during the 21st century. AMBIO 2008, 37, 280-285. [CrossRef]

11. Vicente-Serrano, S.M.; Lasanta, T.; Romo, A. Analysis of spatial and temporal evolution of vegetation cover in the Spanish Central Pyrenees: Role of human management. Environ. Manag. 2005, 34, 802-818. [CrossRef] [PubMed]

12. García-Ruiz, J.M.; Lana-Renault, N. Hydrological and erosive consequences of farmland abandonment in Europe, with special reference to the Mediterranean region-A review. Agric. Ecosyst. Environ. 2011, 140, 317-338. [CrossRef]

13. Beguería, S.; López-Moreno, J.I.; Lorente, A.; Seeger, M.; García-Ruiz, J.M. Assessing the effect of climate oscillations and land-use changes on streamflow in the Central Spanish Pyrenees. AMBIO 2003, 32, 283-286. [CrossRef]

14. López-Moreno, J.I.; Latron, J. Influence of forest canopy on snow distribution in a temperate mountain range. Hydrol. Process 2008, 22, 117-1266. [CrossRef]

15. Cosandey, C.; Andréassian, V.; Martin, C.; Didon-Lescot, J.F.; Lavabre, J.; Folton, N.; Mathys, N.; Richard, D. The hydrological impact of the Mediterranean forest: A review of French research. J. Hydrol. 2005, 301, 235-249. [CrossRef] 
16. López-Moreno, J.I.; Zabalza, J.; Vicente-Serrano, S.M.; Revuelto, J.; Gilaberte, M.; Azorin-Molina, C.; Morán-Tejeda, E.; García-Ruiz, J.M.; Tague, C. Impact of climate and land use change on water availability and reservoir management: Scenarios in the Upper Aragon River, Spain Pyrenees. Sci. Total Environ. 2014, 493, 1222-1231. [CrossRef]

17. Nadal-Romero, E.; Lasanta, T.; García-Ruiz, J.M. Runoff and sediment yield from land under various uses in a Mediterranean mountain area: Long-term results from an experimental station. Earth Surf. Process. Landf. 2013, 38, 346-355. [CrossRef]

18. San-Miguel-Ayanz, J.; Moreno, J.M.; Camia, A. Analysis of large fires in European Mediterranean landscapes: Lessons learned and perspectives. For. Ecol. Manag. 2013, 294, 11-22. [CrossRef]

19. Sitzia, T.; Semenzato, P.; Trentanovi, G. Natural reforestation is changing spatial patterns of rural mountain and hill landscapes: A global overview. For. Ecol. Manag. 2010, 259, 1354-1362. [CrossRef]

20. San Román Sanz, A.; Fernández, C.; Mouillot, F.; Ferrat, L.; Istria, D.; Pasqualini, V. Long-term forest dynamics and land-use abandonment in the Mediterranean mountains, Corsica, France. Ecol. Soc. 2013, 18, 38. [CrossRef]

21. Molinillo, M.; Lasanta, T.; García-Ruiz, J.M. Managing degraded landscape after farmland abandonment in the Central Spanish Pyrenees. Environ. Manag. 1997, 21, 587-598. [CrossRef]

22. San Emeterio, L.; Múgica, L.; Ugarte, M.D.; Goicoa, T.; Canals, R.M. Sustainability of traditional pastoral fires in highlands under global change: Effects on soil function and nutrient cycling. Agric. Ecosyst. Environ. 2016, 225, 155-163. [CrossRef]

23. Morán-Ordoñez, A.; Buster, R.; Suárez-Seoane, S.; de Luis, E.; Calvo, L. Temporal changes in socio-ecological systems and their impact on ecosystems services at different governance scales: A case study of heathlands. Ecosystems 2013, 16, 765-782. [CrossRef]

24. Bernués, A.; Rodríguez-Ortega, T.; Ripoll-Bosch, R.; Alfnes, F. Socio-cultural and economic valuation of ecosystem services provided by Mediterranean agroecosystems. PLoS ONE 2014, 9, e102479. [CrossRef]

25. Fernandes, P.M.; Davies, G.M.; Ascoli, D.; Fernández, C.; Moreira, F.; Rigolot, E.; Stoff, C.R.; Vega, J.A.; Molina, D. Prescribed burning in southern Europe: Developing fire management in a dynamic landscape. Front. Ecol. Environ. 2013, 11, e4-e14. [CrossRef]

26. Lasanta, T.; Nadal-Romero, E.; Errea, M.P.; Arnáez, J. The effects of landscape conservation measures in changing landscape patterns: A case study in Mediterranean mountain. Land Degrad. Dev. 2016, 27, 373-386. [CrossRef]

27. Lasanta, T.; Nadal-Romero, E.; García-Ruiz, J.M. Clearing shrubland as a strategy to encourage extensive livestock farming in the Mediterranean mountains. Cuad. Investig. Geogr. 2019, 45. [CrossRef]

28. Alados, C.L.; Saiz, H.; Nuche, P.; Gartzia, M.; Komac, B.; De Frutos, Á.; Pueyo, Y. Clearing vs. burning for restoring Pyrenean grasslands after shrub encroachment. Cuad. Investig. Geogr. 2019, 45. [CrossRef]

29. Le Houérou, H.N. Agroforestry and sylvopastoralism to combat land degradation in the Mediterranean basin: Old approaches to new problems. Agric. Ecosyst. Environ. 1990, 33, 99-109. [CrossRef]

30. Shalaby, A.; Tateishi, R. Remote sensing and GIS for mapping and monitoring land cover and land-use changes in the Northwestern coastal zone of Egypt. Appl. Geogr. 2007, 27, 28-41. [CrossRef]

31. Gispert, M.; Pardini, G.; Emran, M.; Doni, S.; Masciandaro, G. Seasonal evolution of soil organic matter, glomalin and enzymes and potential for $\mathrm{C}$ storage after land abandonment and renaturalization processes in soils of NE Spain. Catena 2018, 162, 402-413. [CrossRef]

32. Lizaga, I.; Quijano, L.; Gaspar, L.; Ramos, M.C.; Navas, A. Linking land use changes to variation in soil properties in a Mediterranean mountain agroecosystem. Catena 2019, 172, 516-527. [CrossRef]

33. Robledano-Aymerich, F.; Romero-Díaz, A.; Belmonte-Serrato, F.; Zapata-Pérez, V.M.; Martínez-Hernández, C.; Martínez-López, V. Ecogeomorphological consequences of land abandonment in semiarid Mediterranean areas: Integrated assessment of physical evolution and biodiversity. Agric. Ecosyst. Environ. 2014, 197, 222-242. [CrossRef]

34. Cerdà, A.; Rodrigo-Comino, J.; Novara, A.; Brevik, E.C.; Vaezi, A.R.; Pulido, M.; Giménez-Morera, A.; Keesstra, S.D. Long-term impact of rainfed agricultural land abandonment on soil erosion in the Western Mediterranean basin. Prog. Phys. Geogr. 2018, 42, 202-219. [CrossRef]

35. Trudgill, S.T. Introduction. In Solute Processes; J Wiley: Chichester, UK, 1986; pp. 1-14.

36. Smaling, E.M.A.; Oenema, O. Estimating nutrient balances in agro-ecosystems at different spatial scales. In Methods for Assessment of Soil Degradation; CRC Press: Boca Raton, FL, USA, 1997; pp. 229-252. 
37. Han, G.; Li, F.; Tan, Q. Effects of land use on water chemistry in a river draining karst terrain, southwest China. Hydrol. Sci. J. 2014, 59, 1063-1073. [CrossRef]

38. Germer, S.; Neill, C.; Vetter, T.; Chaves, J.; Krusche, A.V.; Elsenbeer, H. Implications of long-term land-use change for the hydrology and solute budget of small catchments in Amazonia. J. Hydrol. 2009, 364, 349-363. [CrossRef]

39. Figuereido, R.O.; Markewitz, D.; Davidson, E.A.; Schuler, A.E.; Watrin, O.; de Souza Silva, P. Land-use effects on the chemical attributes of low-order streams in the Eastern Amazon. J. Geophys. Res. 2010, 115, G04004. [CrossRef]

40. Morales-Martín, L.; Wheater, H.; Lindenschmidt, K.E. Potential changes of annual averaged nutrient export in the South Saskatchewan River Basin under climate and land use change scenarios. Water 2018, 10, 1438. [CrossRef]

41. Llorens, P.; Queralt, I.; Plana, F.; Gallart, F. Studying solute and particulate sediment transfer in a small Mediterranean mountainous catchment subject to land abandonment. Earth Surf. Process. Landf. 1997, 22, 1027-1035. [CrossRef]

42. Outeiro, L.; Úbeda, X.; Farguell, J. The impact of agricultura on solute and suspended sediment load on a Mediterranean watershed after intense rainstorms. Earth Surf. Process. Landf. 2010, 35, 549-560.

43. Nadal-Romero, E.; Lana-Renault, N.; Serrano-Muela, P.; Regüés, D.; Alvera, B.; García-Ruiz, J.M. Sediment balance in four catchments with different land cover in the Central Spanish Pyrenees. Z. Geomorphol. 2012, 56, 147-168. [CrossRef]

44. Oliveira, J.S.; da Cunha Bustamante, M.M.; Markewitz, D.; Krusche, A.V.; Ferreira, L.G. Effects of land cover on chemical characteristics of streams in the Cerrado region of Brazil. Biogeochemistry 2011, 105, 75-88.

45. Ferreira, C.S.S.; Walsh, R.P.D.; Costa, M.; Oliveira Alves, C.; Ferreira, A.J.D. Dynamics of Surface water quality driven by distinct urbanization patterns and storms in a Portuguese peri-urban catchment. J. Soils Sediments 2016, 16, 2606-2621. [CrossRef]

46. Merchán, D.; Luquin, E.; Hernández-García, I.; Campo-Bescós, M.A.; Giménez, R.; Casalí, J.; Del Valle de Lersundi, J. Dissolved solids and suspended sediment dynamics from five small agricultural watersheds in Navarre, Spain: A 10-year study. Catena 2019, 173, 114-130. [CrossRef]

47. Messerli, B.; Vivirioli, D.; Weingartner, R. Mountains of the World-vulnerable water towers for the 21st century. AMBIO Spec. Rep. 2004, 13, 29-34.

48. Boix-Fayos, C.; Martínez-Mena, M.; Arnau-Rosalén, E.; Calvo-Cases, A.; Castillo, V.; Albaladejo, J. Measuring soil erosion by field plots: Understanding the sources of variation. Earth Sci. Rev. 2006, 78, 267-285. [CrossRef]

49. Risking, S.H.; Neill, C.; Jankowski, K.; Krusche, A.V.; McHorney, R.; Elsenbeer, H.; Macedo, M.N.; Nunes, D.; Porder, S. Solute and sediment export from Amazon forest and soybean headwater streams. Ecol. Appl. 2017, 27, 193-207. [CrossRef]

50. Food and Agriculture Organization (FAO). Water Pollution from Agriculture: A Global Review; Food and Agriculture Organization of the United Nations: Rome, Italy; The International Water Management Institute on Behalf of the Water Land and Ecosystems Research Program: Colombo, Sri Lanka, 2017.

51. Lasanta, T.; Cerdà, A. Long-term erosional responses after fire in the Central Spanish Pyrenees. 2. Solute release. Catena 2005, 60, 81-100. [CrossRef]

52. Zavala, L.M.; De Celis, R.; Jordán, A. How wildfires affect soil properties. A brief review. Cuad. Investig. Geogr. 2014, 40, 311-331.

53. Machado, A.; Serpa, D.; Ferreira, R.V.; Rodríguez-Blanco, M.L.; Pinto, R.; Nunes, M.; Cerqueira, M.A.; Keizer, J.J. Cation export by overland flow in a recently burnt forest area in north-central Portugal. Sci. Total Environ. 2015, 524-525, 201-212. [CrossRef]

54. Ferreira, R.V.; Serpa, D.; Machado, A.I.; Rodríguez-Blanco, M.L.; Santos, L.F.; Taboada-Castro, M.T.; Cerqueira, M.A.; Keizer, J.J. Short-term nitrogen losses by overland flow in a recently burnt forest area in north-central Portugal: A study at micro-plot scale. Sci. Total Environ. 2016, 572, 1281-1288. [CrossRef]

55. Ruiz-Flaño, P.; García-Ruiz, J.M.; Ortigosa, L. Geomophological evolution of abandoned fields. A case study in the Central Pyrenees. Catena 1992, 19, 301-308. [CrossRef]

56. Lasanta, T.; Nadal-Romero, E.; Errea, M.P. The footprint of marginal agriculture in the Mediterranean mountain landscape: An analysis of the Central Spanish Pyrenees. Sci. Total Environ. 2017, 599-600, 1823-1836. [CrossRef] 
57. Pueyo, Y.; Alados, C.L.; García-Ávila, B.; Kefi, S.; Maestro, M.; Rietberk, M. Comparing direct abiotic amelioration and facilitation as tools for restoration on semi-arid grassland. Restor. Ecol. 2009, 17, 908-916. [CrossRef]

58. Llorens, P.; Gallart, F. Small basin response in a Mediterranean mountainous abandoned farming area: Research design and preliminary results. Catena 1992, 19, 309-320. [CrossRef]

59. Walling, D.E.; Webb, B.W. Solutes in river systems. In Solute Processes; J Wiley: Chichester, UK, 1986; pp. 251-327.

60. Crabtree, R.W.; Trudgill, S.T. Hydrochemical Budgets for a Magnesium Limestone catchment in low land England. J. Hydrol. 1984, 74, 67-79. [CrossRef]

61. Ruiz-Flaño, P. Procesos de Erosión en Campos Abandonados del Pirineo; Geoforma Ediciones: Logroño, Spain, 1993; 220p.

62. Casali, J.; Giménez, R.; Díez, J.; Álvarez-Mozos, J.; Del Valle de Lersundi, J.; Goñi, M.; Campo, M.A.; Chahor, Y.; Gastesi, R.; López, J. Sediment production and water quality of watersheds with contrasting land use in Navarre (Spain). Agric. Water Manag. 2010, 97, 1683-1694. [CrossRef]

63. Lasanta, T.; Beguería, S.; García-Ruiz, J.M. Geomorphic and hydrological effects of traditional shifting agriculture in a Mediterranean mountain area, Central Spanish Pyrenees. Mt. Res. Dev. 2006, 26, 146-152. [CrossRef]

64. García Ruiz, J.M.; Lasanta, T. El Pirineo aragonés como paisaje cultural. Pirineos 2018, e038. [CrossRef]

65. Pausas, J.G.; Llovet, J.; Rodrigo, A.; Vallejo, R. Are wildfire a disaster in the Mediterranean basin? A review. Int. J. Wildland Fire 2008, 17, 6. [CrossRef]

66. Verburg, P.H.; Overmars, K.P. Combining top-down and bottom-up dynamics in land use modeling: Exploring the future of abandoned farmlands in Europe with the Dyna-CLUE model. Landsc. Ecol. 2009, 24, 1167-1181. [CrossRef]

(C) 2019 by the authors. Licensee MDPI, Basel, Switzerland. This article is an open access article distributed under the terms and conditions of the Creative Commons Attribution (CC BY) license (http://creativecommons.org/licenses/by/4.0/). 